\title{
Cloning and Functional Expression of a Drosophila Metabotropic Glutamate Receptor Expressed in the Embryonic CNS
}

\author{
Marie-Laure Parmentier, Jean-Philippe Pin, Joël Bockaert, and Yves Grau \\ Unité Propre de Recherche-Centre National de la Recherche Scientifique 9023, Mécanismes Moléculaires des \\ Communications Cellulaires, Centre de Pharmacologie-Endrocrinologie, 34094 Montpellier Cedex 5, France
}

The excitatory neurotransmitter glutamate plays important roles in the mammalian brain, ranging from synaptic plasticity to memory. To mediate these functions, glutamate activates two types of receptors: ligand-gated channels and metabotropic receptors coupled to G-proteins. Both families of glutamate receptors share no sequence homology and possess original structural features compared with other ligand-gated channels and G-protein-coupled receptors, respectively. Glutamategated receptor-channel subunits have already been characterized in invertebrates. Here we report the cloning and functional characterization of an invertebrate metabotropic glutamate receptor (DmGluRA) isolated from Drosophila melanogaster. This receptor displays 45 and $43 \%$ amino acid sequence identity with its mammalian homologs mGluR3 and mGluR2, respectively. Moreover, its pharmacology and transduction mechanisms are surprisingly similar to those of mGluR2 and mGluR3. DmGluRA is expressed in the CNS of the late embryo. These results indicate that the original structural features of both glutamate receptor types are conserved from insects to mammals and suggest that the functions of these receptors have been highly conserved during evolution.

Key words: CNS; Drosophila melanogaster; glutamate; G-protein coupling; metabotropic glutamate receptor; embryogenesis; adenylyl cyclase inhibition
Glutamate is the major excitatory neurotransmitter in the vertebrate CNS. To mediate fast synaptic transmission, it activates AMPA- and NMDA-selective ionotropic receptors (Hollmann and Heinemann, 1994), the latter playing important roles in synaptic plasticity, neurotoxicity, development, and memory formation. In addition, glutamate activates G-protein-coupled metabotropic receptors (mGluRs), which can modulate or mediate neurotransmission and play a role in long-term changes in synaptic efficacy (Pin and Duvoisin, 1995). This makes them essential for functions as diverse and important as developmental plasticity (Dudek and Bear, 1989; Catania et al., 1994), vision (Masu et al., 1995), olfactory memory (Hayashi et al., 1993; Kaba et al., 1994), spatial memory, and motor control (Aiba et al., 1994; Conquet et al., 1994). Eight mGluRs (mGluR1-8) have been cloned in vertebrates (Nakanishi, 1994; Pin and Duvoisin, 1995). They can be classified into three groups based on their amino acid sequence identity, pharmacology, and transduction mechanism. mGluR1 and mGluR5 are coupled to phospholipase C (PLC) and constitute the first group. mGluR2/3 and mGluR4, $-6,-7$, and -8

\footnotetext{
Received June 26, 1996; revised Aug. 7, 1996; accepted Aug. 12, 1996.

This work was supported by grants from the Centre National de la Recherche Scientifique, European Community (BIOMED2-BMH4-CT96-0228), Direction des Recherches et Etudes Techniques (95075), the French Ministry of Education, Research and Professional Insertion (ACC-SV5, 9505077), and Bayer Company (France and Germany). We thank Drs. C. Dambly-Chaudière and A. Ghysen for critical reading of this manuscript and for constructive discussions. We thank Drs. B. Conklin and $\mathrm{H}$. Bourne (University of California San Francisco, San Francisco, CA) for the gift of the wild-type and chimeric $G_{\alpha q}$ subunit cDNAs. We thank Dr. F. Lemeunier for her assistance with in situ hybridization to polytene chromosomes, J. Britton-Davidian for access to microscopic equipment, and P. David for his help with the UPGMA analysis. We also gratefully acknowledge V. Brand for stimulating discussions, C. Joly for technical assistance, L. Charvet for the iconography, and M. Passama for the bibliographic searches.

Correspondence should be addressed to Y. Grau, Centre de Pharmacologie, 141 Rue de la Cardonille, 34094 Montpellier Cedex 5, France.

Copyright (C) 1996 Society for Neuroscience $0270-6474 / 96 / 166687-08 \$ 05.00 / 0$
}

inhibit adenylyl cyclase (AC) and constitute the second and third groups, respectively.

Both ionotropic and metabotropic glutamate receptors share no sequence and structural homology with the other ligand-gated channels and G-protein-coupled receptors (GPCRs), respectively (Hollmann and Heinemann, 1994). Indeed, metabotropic glutamate receptors constitute, with the calcium-sensing receptor (Brown et al., 1993), a new family of GPCRs. Their ligand binding site is located in a large N-terminal extracellular domain homologous to bacterial periplasmic binding proteins (O'Hara et al., 1993), whereas for most other GPCRs it is located in a cavity formed by the seven transmembrane domains. Moreover, the specificity of interaction with G-proteins is determined by the second intracellular loop in mGluRs (Pin et al., 1994; Gomeza et al., 1996a) and by the third intracellular loop in most other GPCRs (Liu et al., 1995).

In arthropods, glutamate is well known as the transmitter at the neuromuscular junction (Jan and Jan, 1976; Delgado et al., 1989). It is also recognized as a transmitter in the invertebrate CNS (Bicker et al., 1988), where it has both excitatory and inhibitory actions (Bolshakov et al., 1991; Kehoe, 1994; Parker, 1994). Indeed, subunits of glutamate-gated cationic channel receptors have been cloned in nematodes (Hart et al., 1995; Maricq et al., 1995), in Lymnea (Hutton et al., 1991; Stühmer et al., 1996), and in Drosophila (Schuster et al., 1991; Ultsch et al., 1992, 1993). These cationic receptor subunits are homologous to the mammalian ionotropic glutamate receptor subunits. In contrast, an anionic glutamate-gated receptor cloned from Caenorhabditis elegans (Cully et al., 1994) is homologous to the mammalian GABA/ glycine receptor subunits. The Drosophila subunit DGluRI, the molluscan kainate-type receptor, and the nematode AMPA-type receptor GLR-1 are expressed in the CNS, whereas the Drosophila receptor subunit DGluRII is expressed in muscle cells. Mutations in GLR-1 lead to abnormal mechanosensory signaling (Hart 
et al., 1995; Maricq et al., 1995). Moreover, a sequence homologous to mammalian mGluRs has been found by systematic sequencing of $C$. elegans genome (Wilson et al., 1994). Taken together, these data suggest important functions for glutamate in invertebrates.

Here we report the isolation of a cDNA encoding a Drosophila metabotropic glutamate receptor, called DmGluRA, homologous to the mammalian mGluR family and especially to group II mGluRs. In mammalian-transfected cells, DmGluRA behaves as a functional glutamate receptor negatively coupled to AC. Its pharmacology is very close to that of mGluR2. It is expressed in the adult and in the CNS of the Drosophila late embryo.

\section{MATERIALS AND METHODS}

Materials. AMPA, L-quisqualate, (2S,3S,4S)- $\alpha$-(carboxycyclopropyl)glycine (L-CCG-I), (2S, 3S, 4S)-2-methyl-2-(carboxycyclopropyl)glycine (MCCG-I), (S)-4-carboxy-3-hydroxyphenylglycine (4C3HPG), (S)-3hydroxyphenylglycine (3HPG), (RS)-3,5-dihydroxyphenylglycine (DHPG), L-2-amino-4-phosphonobutanoate (L-AP4), (S)-2-amino-2-methyl-4phosphonobutyrate (MAP4), L-serine- $o$-phosphate (L-SOP), (RS)- $\alpha$-methyl4-phosphonophenylglycine (MPPG), (RS)- $\alpha$-methyl-4-carboxyphenylglycine (MCPG), (RS)- $\alpha$-methyl-4-tetrazolylphenylglycine (MTPG), and (RS)- $\alpha$ methyl-4-sulfonophenylglycine (MSPG) were obtained from Tocris Cookson (Essex, UK). The two isomers 1S,3S-1-amino-1,3-cyclopentanedicarboxylate (1S,3S-ACPD) and 1S,3R-1-amino-1,3-cyclopentanedicarboxylate (1S,3RACPD) were a generous gift of Dr. K. Curry (Vancouver, Canada). NMDA, glutamate, and kainic acid were from Sigma-Aldrich (L'isle d'Abeau, France).

Cloning of DmGluRA. A set of primers was used to amplify the cDNA fragments coding for the transmembrane region. The sense primer aMDM55 (5'-TA(C/T) AG(C/T) GT(G/A/T/C) CT(A/G) CTI AC(G/A/ $\left.\mathrm{T} / \mathrm{C}) \mathrm{AA}(\mathrm{A} / \mathrm{G}) \mathrm{AC}-3^{\prime}\right)$ and the antisense primer aMDM43 $\left(5^{\prime}-\mathrm{CC}(\mathrm{A} / \mathrm{G})\right.$ $\mathrm{AT}(\mathrm{G} / \mathrm{A} / \mathrm{T} / \mathrm{C})$ AT(A/G) CAI GTI GT(A/G) TAC AT-3') correspond to the consensus sequences found in transmembrane domains III and VI. A cDNA library (gift from L. Jan, University of California San Francisco, San Francisco, CA) prepared from heads of wild-type Oregon R Drosophila was used as a template. A band of 480 bp was obtained after 40 cycles of amplification (denaturation at $94^{\circ} \mathrm{C}$ for $1 \mathrm{~min}$, annealing at $52^{\circ} \mathrm{C}$ for $45 \mathrm{sec}$, and elongation at $72^{\circ} \mathrm{C}$ for $1 \mathrm{~min}$ ). After subcloning into the pBluescript vector, the PCR fragments were sequenced using the dideoxy technique. One clone homologous to mGluRs was obtained and random prime-labeled to screen the cDNA library at high stringency $\left(42^{\circ} \mathrm{C}, 50 \%\right.$ formamide, $5 \times \mathrm{SSC}, 5 \times \mathrm{PAF}, 0.5 \% \mathrm{SDS}$, and 20 $\mu \mathrm{g} / \mathrm{ml}$ salmon sperm DNA).

Sequence of the 3358 bp DmGluRA cDNA was performed on both strands by the dideoxy technique using successive synthetic oligonucleotides.

Construction of DmGluRA expression vector. The Bam HI-Asn I fragment of DmGluRA was inserted into the expression vector pRK7 digested with BamHI, with SmaI giving the pRKDGAs clone.

DmGluRA Kosak sequence was modified by PCR to fit the mammalian consensus sequence (Cavener, 1987). Sense primer was (5'-CGG GGA TCC ACC ATG AAA CAG AAA AAT AAT AAC-3') with a BamHI restriction site, and antisense primer was (5'-CGT AAA AAG AAC AAC GCC G-3'). The PCR product and the pRKDGAs clone were digested with Bam HI and PpuM I, gel-purified, and ligated. The resulting recombinant was called KosDMGRAs.

Culture and transfection of HEK 293 cells. Cells were cultured in DMEM (Life Technologies, Gaithersburg MD) supplemented with $10 \%$ fetal calf serum and antibiotics (penicillin and streptomycin, $100 \mathrm{U} / \mathrm{ml}$ final). Electroporation was performed in a total volume of $300 \mu \mathrm{l}$ with $12.5 \mu \mathrm{g}$ of carrier DNA (plasmid DNA without insert), $5 \mu \mathrm{g}$ of KosDMGRAs with $6 \mu \mathrm{g}$ of Gqi9, Gqi5, or Gqwt (in pCDNAI, Invitrogen, San Diego, CA), or with $600 \mathrm{ng}$ luteinizing hormone ( $\mathrm{LH})$ receptor (in pRK8) for $1 \times 10^{7}$ cells in electroporation buffer $\left(\mathrm{K}_{2} \mathrm{HPO}_{4}, 50 \mathrm{~mm}\right.$; CH3COOK, $20 \mathrm{~mm}$; KOH, $20 \mathrm{~mm})$. After electroporation $(270 \mathrm{~V}, 950 \mu \mathrm{F}$, Biorad gene pulser electroporator), cells were resuspended in DMEM supplemented with $10 \%$ FCS and antibiotics and split into 12-well clusters $\left(5 \times 10^{6}\right.$ cells per cluster $)$ precoated with poly-L-ornithine $[15 \mu \mathrm{g} / \mathrm{ml}$; molecular weight (MW) 40,000; Sigma-Aldrich].

Determination of cAMP accumulation. The cellular cAMP production was measured using the prelabeling technique. Four hours after being electroporated, cells were washed and incubated for $14 \mathrm{hr}$ in DMEM glutamax I (Life Technologies, Cergy Pontoise, France) containing 1 $\mu \mathrm{Ci} / \mathrm{ml}\left[{ }^{3} \mathrm{H}\right]$ adenine $(27 \mathrm{Ci} / \mathrm{mmol})$ and pertussis toxin $(\mathrm{PTX})(100 \mathrm{ng} / \mathrm{ml})$ when indicated. Cells were then washed three times and incubated for 1.5 hr at $37^{\circ} \mathrm{C}$ in $1 \mathrm{ml}$ of HEPES buffer saline (in mM): $146 \mathrm{NaCl}, 4.2 \mathrm{KCl}, 0.5$ $\mathrm{MgCl}_{2}, 20$ HEPES, and glucose $0.1 \%$, pH 7.4. Cells were then washed again twice with the same medium, incubated for 8 min with $0.75 \mathrm{~mm}$ 3-isobutyl-1-methyl-xanthine (Sigma), and stimulated for $10 \mathrm{~min}$ with 100 $\mathrm{ng} / \mathrm{ml} \mathrm{LH}$ (Sigma) or $1 \mathrm{~mm}$ Glu or both. The reaction was stopped by aspiration of the media and addition of $1 \mathrm{ml}$ of ice-cold 5\% trichloroacetic acid. Cells were scraped, and $100 \mu \mathrm{l}$ of $10 \mathrm{~mm}$ ATP and $10 \mathrm{~mm}$ cAMP were added to the mixture. Cellular proteins were removed by centrifugation at $5000 \times g$, and $\left[{ }^{3} \mathrm{H}\right]$-ATP and $\left[{ }^{3} \mathrm{H}\right]$-cAMP were separated by sequential chromatography on Dowex and alumina columns. cAMP formation is expressed as percentage conversion of $\left[{ }^{3} \mathrm{H}\right]$-ATP to $\left[{ }^{3} \mathrm{H}\right]$-cAMP: $\left(\left[{ }^{3} \mathrm{H}\right]\right.$-cAMP $\left.\times 100\right) /\left(\left[{ }^{3} \mathrm{H}\right]\right.$-cAMP $\left.+\left[{ }^{3} \mathrm{H}\right]-\mathrm{ATP}\right)$.

Determination of inositol phosphate (IP) accumulation. Determination of IP accumulation in transfected cells was performed as described previously (Joly et al., 1995). Four hours after electroporation, cells were washed and incubated for $14 \mathrm{hr}$ in DMEM-glutamax I containing 1 $\mu \mathrm{Ci} / \mathrm{ml}$ myo- $\left[{ }^{3} \mathrm{H}\right]$ inositol $(22.9 \mathrm{Ci} / \mathrm{mmol})$. Cells were then washed three times and incubated in HEPES saline buffer for $1 \mathrm{hr}$ with $3 \mu \mathrm{g} / \mathrm{ml}$ glutamate pyruvate transaminase (Boehringer Mannheim, Meylan, France) and $2 \mathrm{~mm}$ pyruvate. Cells were then washed twice and incubated for $5 \mathrm{~min}$ in medium containing $10 \mathrm{~mm} \mathrm{LiCl}$. Agonists were then added for a period of $30 \mathrm{~min}$. Antagonists were added just before agonists during the $\mathrm{LiCl}$ preincubation. The reaction was stopped by replacing the incubation medium with $1 \mathrm{ml} 5 \%$ perchloric acid. The total IP was then extracted and purified on Dowex columns as described previously (Joly et al., 1995). Total radioactivity remaining in the membrane fraction was counted after solubilization in $10 \%$ Triton $0.1 \mathrm{~N} \mathrm{NaOH}$ and used as standard. Results are expressed as the amount of IP produced over the radioactivity present in the membranes.

RT-PCR of DmGluRA. Total RNA was extracted from Drosophila by the guanidium isothiocyanate method (Chomczynski and Sacchi, 1987). PolyA RNA was obtained with the RNA Flash Kit (Bioprobe Systems, Montreuil, France). One microgram of polyA RNA was reversetranscribed with $50 \mu \mathrm{M}-\mathrm{MLV}$ reverse transcriptase (Life Technologies) in a $20 \mu \mathrm{l}$ reaction containing $100 \mathrm{pmol}$ of nonamer random primers (Bioprobe Systems, Montreuil, France), $1 \mathrm{~mm}$ dNTPs, and 10 mM DTT in the reaction buffer supplied by the manufacturer. The PCR reaction was performed using $2 \mu \mathrm{l}$ of the RT reaction with the sense primer dec 8s (5'-ATG CGA CGA TAG TTA CCG G-3') and the antisense primer dec $18 \mathrm{r}$ ( $5^{\prime}$-ACC TAC TTC GGC CTG TTC A-3'). Reaction was as follows: 30 cycles of denaturation at $94^{\circ} \mathrm{C}$ for $1 \mathrm{~min}$, annealing at $56^{\circ} \mathrm{C}$ for $45 \mathrm{sec}$, and elongation at $72^{\circ} \mathrm{C}$ for $1 \mathrm{~min}$. The PCR products were subcloned into pGEM-T vector (Promega, Charbonnières, France) and sequenced. A Southern blot of these PCR products was realized at high stringency $\left(42^{\circ} \mathrm{C}, 50 \%\right.$ formamide, $5 \times$ SSC, $5 \times$ PAF, $0.5 \%$ SDS, and $20 \mu \mathrm{g} / \mathrm{ml}$ salmon sperm DNA) using a radiolabeled DmGluRA probe.

Whole-mount embryo in situ hybridization. DmGluRA transcripts were localized by whole-mount in situ hybridization with a digoxygenin-labeled probe (Lehmann and Tautz, 1994). Two hundred nanograms of the EcoRI fragment of DmGluRA were amplified with $0.6 \mathrm{~mm}$ of a mix of 6 sense or 6 antisense oligos dispersed on the whole sequence, with DIG DNA labeling mix (Boehringer Mannheim) diluted $5 \times$, and with $1 \mathrm{U}$ of Vent DNA polymerase. The amplification was performed using 30 cycles: $94^{\circ} \mathrm{C}$ for $1 \mathrm{~min}, 52^{\circ} \mathrm{C}$ for $45 \mathrm{sec}$, and $72^{\circ} \mathrm{C}$ for $1 \mathrm{~min}$. The probe was then boiled for $30 \mathrm{~min}$ to reduce the DNA size. Dechorionated and devitelinized embryos were incubated overnight at $46^{\circ} \mathrm{C}$ in $50 \%$ formamide, $5 \times$ SSC, $0.1 \%$ Tween 20, $100 \mu \mathrm{g} / \mathrm{ml}$ salmon sperm DNA, and $50 \mu \mathrm{g} / \mathrm{ml}$ heparin solution, with the probe diluted 60 times. Embryos were then washed progressively in $1 \times$ PBS, $0.1 \%$ Tween 20 at $46^{\circ} \mathrm{C}$, incubated with anti-digoxygenine antibody conjugated with alkaline phosphatase for $1 \mathrm{hr}$ at room temperature, washed again, and incubated with alkaline phosphatase substrates.

In situ hybridization to polytene chromosome. Drosophila salivary gland polytene chromosome squashes were hybridized with biotinylated DNA probes obtained by nick-translation. Hybridizations were performed as described (Pardue, 1994) at $37^{\circ} \mathrm{C}$ with $50 \%$ formamide and $4 \times$ SSC. 


\section{RESULTS}

\section{Cloning and analysis of DmGluRA}

Cloning of Drosophila mGluRs homologs was performed through a PCR approach using degenerated oligonucleotides corresponding to the transmembrane domains III and VI highly conserved in the mGluR family. From all PCR products obtained using Drosophila head cDNAs as template, one sequence was found to be homologous to rat mGluRs. This fragment was used to screen a $\lambda$-Zap Drosophila head cDNA library to get the corresponding cDNA, which was called DmGluRA. It contains a 2.9-kb-long open reading frame with $5^{\prime}$ and $3^{\prime}$ untranslated regions but no polyadenylation signal.

The deduced amino acid sequence of DmGluRA contains 977 amino acid residues corresponding to a protein of a predicted MW of $108 \mathrm{kDa}$. This protein sequence reveals that all of the structural features characteristic of the mammalian mGluRs are conserved in DmGluRA: a putative N-terminal signal peptide, a large extracellular domain with a cysteine-rich region, seven putative transmembrane segments that give rise to three short intracellular loops (i1, i2, i3), and a C-terminal tail (Fig. 1). All of the cysteines conserved in the mammalian mGluRs are also conserved in DmGluRA.

DmGluRA is most homologous to group II mGluRs $(45 \%$ amino acid identity with mGluR3 and $43 \%$ with mGluR2). A dendrogram constructed with the percentages of identity between DmGluRA and rat mGluRs and the bovine parathyroid calciumsensing receptor (CaR) shows that DmGluRA belongs to the subgroup formed by groups II and III mammalian mGluRs (Fig. 2). DmGluRA branches with group II rather than group III, although this relies only on a slight difference in the percentage of identity $(5 \%)$.

\section{Transduction mechanism of DmGluRA}

To determine its transduction pathway, DmGluRA was transiently expressed into human embryonic kidney (HEK 293) cells. Glutamate elicited neither cAMP nor IP formation in cells expressing DmGluRA (Fig. $3 A, B$ ). In cells coexpressing DmGluRA and the LH receptor, glutamate induced a strong inhibition of the LH-stimulated cAMP production (Fig. $3 A$ ). No such inhibition was observed after pretreatment of the cells with Bordetella PTX (Fig. $3 A$ ) or in cells expressing the $\mathrm{LH}$ receptor alone (data not shown). PTX is known to prevent the activation of $G_{i}$ and $G_{o}$ G-proteins, the $G_{i}$ proteins often being involved in the negative coupling of receptors to AC. This indicates that DmGluRA is negatively coupled to AC like the group II and III mammalian mGluRs.

To further define the G-protein-coupling specificity of DmGluRA, its coupling to chimeric G-proteins was analyzed. The $\alpha$-subunit of $\mathrm{G}_{\mathrm{q}}\left(\mathrm{G}_{\alpha \mathrm{q}}\right)$ is known to couple GPCRs to PLC, whereas the $G_{\alpha i}$ subunits negatively couple GPCRs to AC, the coupling to $\mathrm{K}^{+}$and $\mathrm{Ca}^{2+}$ channels being mediated by either the $\mathrm{G}_{\mathrm{i}}$ or $\mathrm{G}_{\mathrm{o}}$ type of G-proteins (Birnbaumer and Birnbaumer, 1995). The few last C-terminal residues of these $\alpha$-subunits are known to be involved in the specificity of interaction between the G-protein and the receptor (Conklin and Bourne, 1993). Accordingly, the chimeric $G_{\alpha q}$-proteins in which the five or nine C-terminal residues have been replaced by those of $\mathrm{G}_{\alpha \mathrm{i}}\left(\mathrm{G}_{\alpha \mathrm{qi} 5}\right.$ or $\left.\mathrm{G}_{\alpha \mathrm{qi} 9}\right)$ or $\mathrm{G}_{\alpha \mathrm{o}}$ $\left(\mathrm{G}_{\alpha \mathrm{qo5}}\right)$ allow many $\mathrm{G}_{\mathrm{i}} / \mathrm{o}_{\mathrm{o}}$-coupled receptors to activate PLC (Conklin et al., 1993). In cells coexpressing DmGluRA and these chimeric $\mathrm{G}_{\alpha}$ proteins, glutamate elicited a threefold stimulation of IP production (Fig. $3 B$ ). No such stimulation was observed when DmGluRA was coexpressed with the wild-type $G_{\alpha q}$ protein, indi-
Table 1. Pharmacological characterization of DmGluRA

\begin{tabular}{llll} 
Agonists & $\mathrm{EC}_{50}$ SEM & Antagonists & $\mathrm{IC}_{50}$ SEM \\
\hline Glu & $1.2 \pm 0.05$ & ( \pm )MCPG & $>1000$ \\
1S,3S-ACPD & $41 \pm 6$ & MCCG-I & $201 \pm 45$ \\
1S,3R-ACPD & $65 \pm 2$ & (RS)-MPPG & $513 \pm 125$ \\
L-CCG-I & $11 \pm 1$ & (RS)-MSPG & $>1000$ \\
(S)-4C3HPG & $20 \pm 3$ & (RS)-MTPG & $348 \pm 32$ \\
L-Quis & $28 \pm 9$ & (S)-MAP4 & $>1000$ \\
L-AP4 & $>1000$ & &
\end{tabular}

Values are $\mathrm{EC}_{50}$ and $\mathrm{IC}_{50}$ (in $\mu \mathrm{M}$ ), determined as described in Materials and Methods, and are means \pm SEM of three independent experiments performed in triplicates. For agonists, $>1000$ means the molecule at $1 \mathrm{~mm}$ induced a response $<50 \%$ of the maximal effect of glutamate. For antagonists, $>1000$ means the molecule at $1 \mathrm{~mm}$ induced $<50 \%$ inhibition of the $3 \mu \mathrm{m}$ glutamate effect.

cating that the $\mathrm{C}$-terminal sequence of $\mathrm{G}_{\alpha \mathrm{i}}$ or $\mathrm{G}_{\alpha \mathrm{o}}$ is necessary for the coupling of the G-protein to DmGluRA.

\section{Pharmacology of DmGluRA}

The measurement of IP production after coexpression of DmGluRA and $\mathrm{G}_{\alpha q i 9}$ was more sensitive and accurate than the measurement of the inhibition of LH-stimulated cAMP production. Moreover, the pharmacological profiles of the $\mathrm{G}_{\mathrm{i}}$-coupled mGluR2 and mGluR4 determined by this IP assay were found to be similar to those reported previously by measuring AC inhibition in cell lines stably expressing these receptors (Gomeza et al., 1996b). This assay therefore was used to establish the pharmacology of DmGluRA. None of the ionotropic receptor agonistsAMPA, kainate, and NMDA — had any activity at $300 \mu \mathrm{M}$. The specific and potent group I mGluRs agonists $3 \mathrm{HPG}$ and DHPG (Ito et al., 1992) were inactive at a concentration up to $100 \mu \mathrm{M}$; however, group II and III agonists 1S,3S-ACPD and L-CCG-I (Hayashi et al., 1992; Cartmell et al., 1993) were active. Among group III-specific agonists (Pin and Duvoisin, 1995), L-AP4 gave a small response and L-SOP was inactive at $1 \mathrm{~mm}$. 4C3HPG, which is a group I antagonist and a group II agonist (Hayashi et al., 1994), was found to be an agonist of DmGluRA. The order of potency of the different agonists of DmGluRA was Glu $>$ L-CCGI $>4$ C 3 HPG $>$ quisqualate $>1$ S,3S-ACPD $\approx 1 \mathrm{~S}, 3 \mathrm{R}-\mathrm{ACPD}>$ L-AP4 (Fig. 3C, Table 1). Among these, Glu had the best efficacy followed by 4C3HPG, 1S,3S-ACPD, 1S,3R-ACPD, and L-CCG-I.

Among the antagonists tested, the group II-specific antagonist MCCG-I, as well as MPPG and MTPG (group II and group III antagonists) (Roberts, 1995), totally inhibited the glutamate response in a dose-dependent manner (Fig. 3D). Their order of potency was MCCG-I > MPPG $\approx$ MTPG. MAP4, a group III antagonist (Roberts, 1995), and MCPG, more potent on group I mGluRs, reduced the glutamate response to 50 and $32 \%$ of the maximum at $1 \mathrm{~mm}$, respectively.

\section{Localization of DmGluRA mRNAs}

Embryonic expression of DmGluRA was studied by in situ hybridization with a digoxigenin-labeled antisense probe. No signal was detected until stage 10, where a transient labeling was observed in the cephalic region (Fig. 4A). No such labeling was observed when the sense probe was used (data not shown). At this stage, stomodeal invagination takes place, giving rise to the anterior and posterior labia. In the posterior labium, two symmetrical clusters of two or three epithelial cells were labeled. In the anterior labium, two clusters of 5-10 cells were also labeled. The anterior and posterior clusters were close to the median plane in the early stage 10 , but the anterior ones moved to the lateral ends of the 


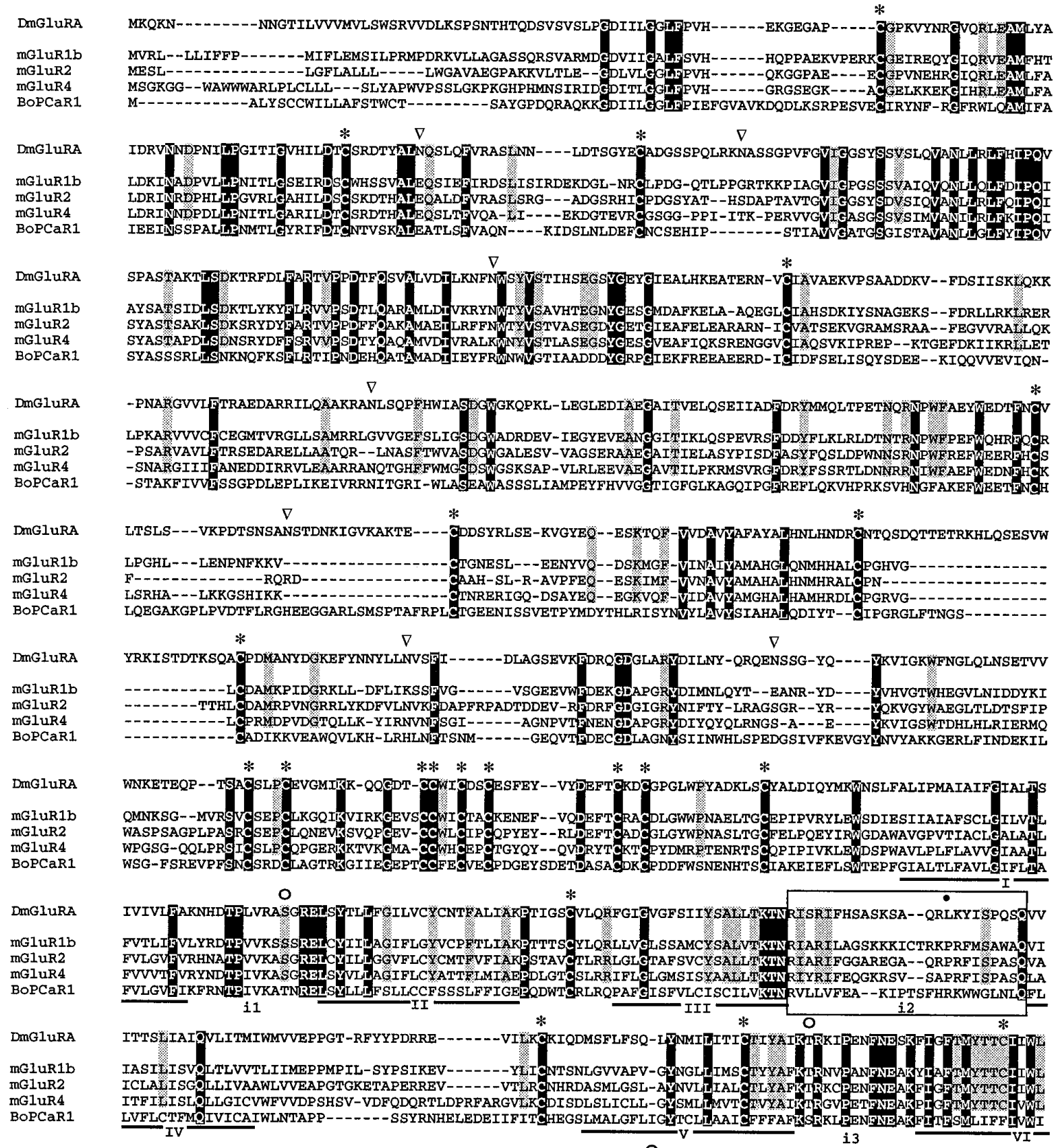

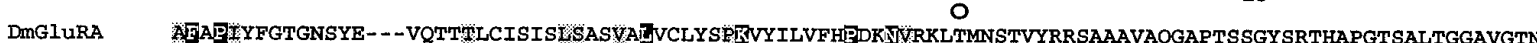

mGluR1b

mGluR2

mGluR4

BOPCaR1

DMGIURA

mGIUR $1 b$

mGluR2

mGluR4

BOPCaRI

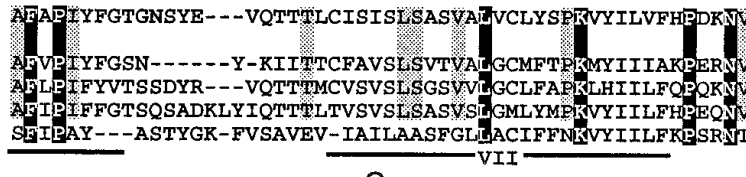

O

ASSSTLPTQNSPHLDEASAQTNVAHKTNGEFLPEVGERVEPICHIVNK

QPEFSPSSQCPSAHAQL

TKQTYVTYTNHAI

SSKSNSEDPFPQQQPKRQKQPQPLALSPHNAQQPQPRPPSFGSGTVTFSLSFDEPQKTAVAHRNSTHQTSLEAQKNNDALTKHQALLPLQCGETDSELTS

BOPCaR1

QETGLQGPVGEDHQLEMEDPEEMSPALVVSNSRSFVISGGGSTVTENMLRS

Figure 1. Multiple alignment of DmGluRA with one rat mGluR from each group and with the bovine calcium-sensing receptor. Residues conserved in the entire mGluR family (including those not represented in the figure) and in the calcium-sensing receptor are highlighted in black. Residues conserved only in the entire mGluR family are highlighted in gray. Conserved cysteines are indicated by an asterisk, and potential $N$-glycosylation sites in DmGluRA by $\nabla$. Leucine 730 of DmGluRA is indicated by $\mathbf{0}$, and potential phosphorylation sites of this receptor (by protein kinase A and casein kinase II) are indicated by $\bigcirc$. The sequence of the second intracellular loop is bordered in black. The position of transmembrane domains I-VII is underlined in black. The sequence of the cDNA, from which the DmGluRA protein was deduced, has been given the EMBL accession number X99675. 


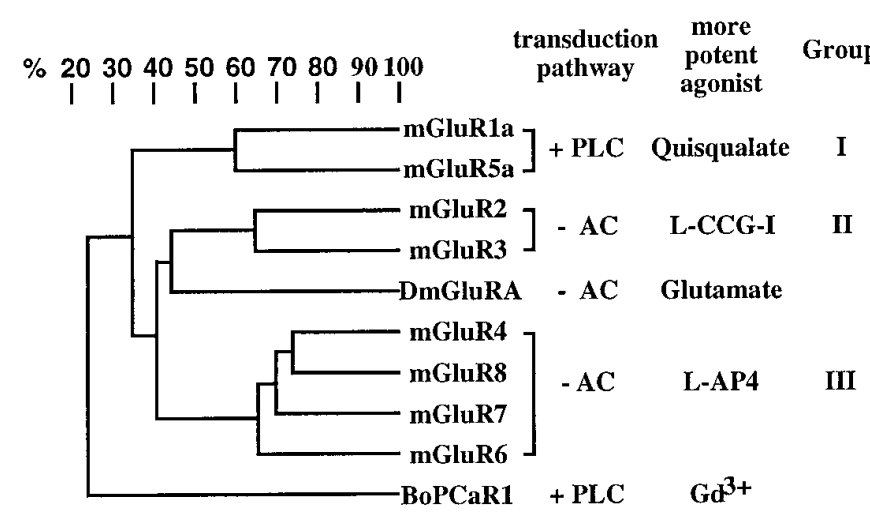

Figure 2. UPGMA dendrogram using pairwise amino acid identities (indicated in percentages) between all members of the mGluR family and bovine parathyroid $\mathrm{CaR}$ as an outgroup. Cophenetic correlation coefficient was 0.99 , indicating an overall very good fit.

labium in the late stage 10. Moreover, the cells of these anterior clusters were not only epithelial but were also subepithelial. This labeling completely disappeared at stage 11. Later in development, at stage 14 , we observed a weak labeling restricted to the CNS (Fig. 4B). This labeling became stronger until stage 17 (Fig. $4 C$ ). At this stage, DmGluRA RNAs were expressed in many of the ventrolateral cells of the abdominal CNS as well as in 6-10 median cells of every abdominal segment (Fig. 4D). The expression in the thoracic segments and in sub- and supraesophageal ganglions was high and difficult to resolve at the cellular level.

The expression of DmGluRA in the adult was detected by RT-PCR (Fig. 5), in both the head (including the brain) and the rest of the body of the animal (including the thoracic and abdominal ganglia).

\section{Mapping of the gene encoding DmGluRA}

The location of the gene encoding DmGluRA was identified by in situ hybridization of biotin-labeled DmGluRA probes to Drosophila salivary gland chromosomes. Hybridization was observed at position $102 \mathrm{CD}$ of the fourth chromosome (data not shown).

\section{DISCUSSION}

We report here the cloning and functional characterization of an invertebrate mGluR: DmGluRA. Its deduced primary sequence reveals that all of the characteristics of mammalian mGluRs are conserved in DmGluRA. Moreover, the 19 cysteine residues conserved in the mammalian mGluR-CaR receptor family are also conserved in DmGluRA. These residues are therefore likely to play important roles in the functioning of these receptor proteins, possibly being involved in intramolecular transduction (O'Hara et al., 1993). DmGluRA is more related to group II mammalian mGluRs, as shown by the unweighted pair-group method of arithmetic averages (UPGMA) analysis. It shares $\sim 45$ and $43 \%$ amino acid identity with mGluR3 and mGluR2, respectively. Similar percentages of identity were reported between two Drosophila ionotropic GluRs and their mammalian homologs (44\% for DGluR I with GluR3, 46\% for DNMDAR-I with NMDARI) (Ultsch et al., 1992, 1993). These observations suggest that the group II mGluR existed in the common ancestor of arthropods and vertebrates. Consequently, we can suppose that mGluRs corresponding to the other subgroups are also present in Drosophila.

When expressed in HEK 293 cells, DmGluRA activates neither AC nor PLC but is negatively coupled to AC in a PTX-sensitive
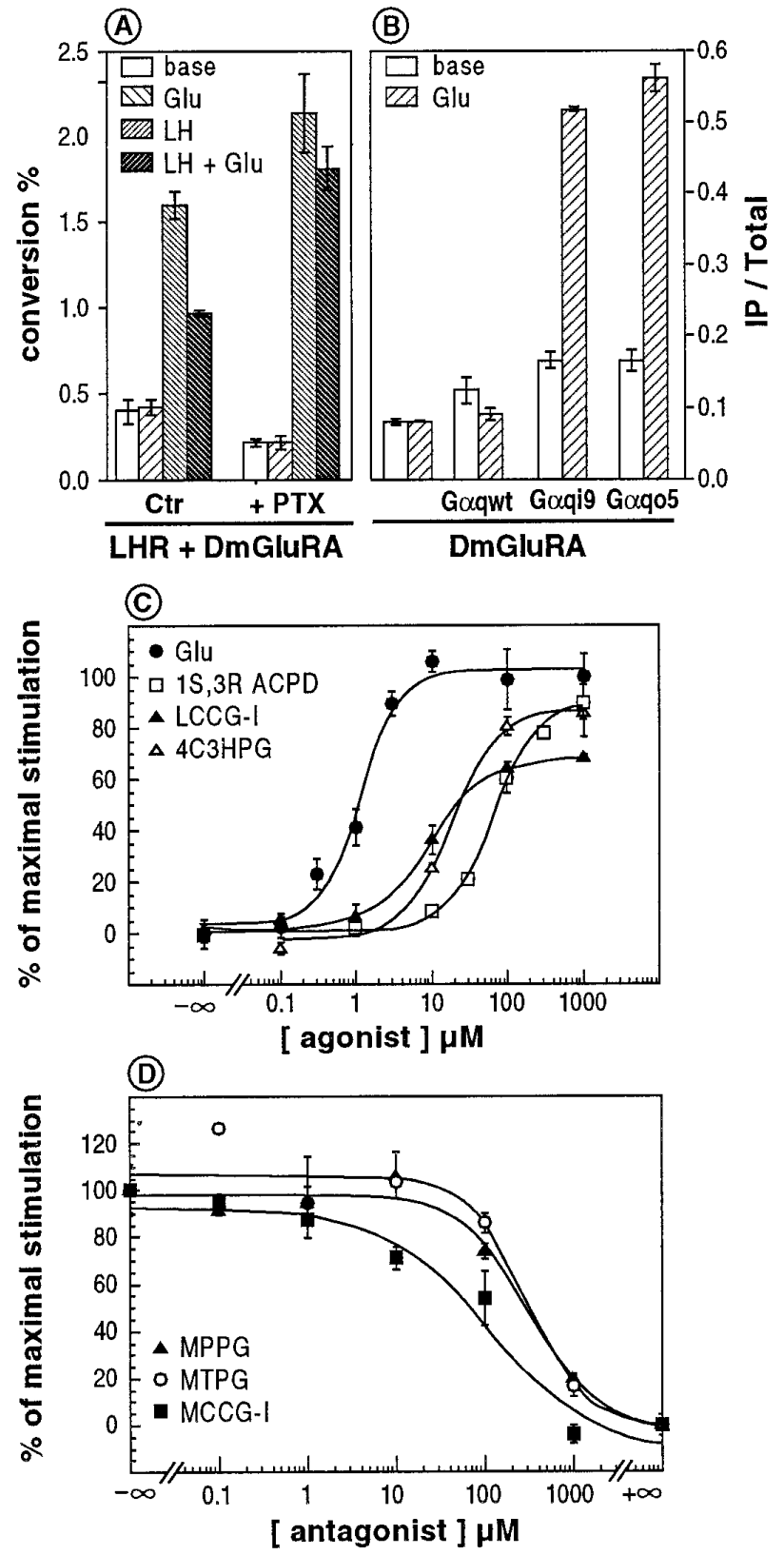

Figure 3. Transduction mechanism and pharmacology of DmGluRA. A, Cotransfection of DmGluRA and LH receptor $(L H R)$. Percentage of conversion of ATP in cAMP is estimated in the presence of either $1 \mathrm{mM}$ glutamate or $100 \mathrm{ng} / \mathrm{ml} \mathrm{LH}$ or in the presence of both agonists. The same experiment is repeated on cells pretreated with $100 \mathrm{ng} / \mathrm{ml}$ PTX. $B$, Measure of IP production after application of $1 \mathrm{~mm}$ glutamate on cells expressing DmGluRA alone or DmGluRA with wild-type $\mathrm{G}_{\alpha \mathrm{q}}(G \alpha q w t)$ or $\mathrm{G}_{\alpha q i 9}$ or $\mathrm{G}_{\alpha q \circ 5} . C$, Dose-response curves of agonist-induced IP stimulation (expressed in percent of maximal glutamate stimulation) when DmGluRA was cotransfected with $\mathrm{G}_{\alpha \mathrm{qi}}$. $D$, Activation of IP production by $3 \mu \mathrm{M}$ glutamate in the presence of variable concentrations of antagonists. In $C$ and $D$, curve fittings were realized using Kaleidagraph software [fitting equation: $y=(\mathrm{m} 1-\mathrm{m} 2) /(1+(x / \mathrm{m} 4) \mathrm{m} 3)+\mathrm{m} 2 ; \mathrm{m} 1=$ response when $x=$ $0 ; \mathrm{m} 2=$ response when $x=\infty ; \mathrm{m} 3=$ slope $; \mathrm{m} 4=\mathrm{EC}_{50}$ or $\left.\mathrm{IC}_{50}\right]$. Values are means \pm SEM of triplicate determinations from typical experiments.

manner, like its mammalian homologs. Because $\mathrm{G}_{\alpha \mathrm{o}}$ is absent in HEK 293 cells (Law et al., 1993), our results indicate that DmGluRAs do couple to human $\mathrm{G}_{\alpha \mathrm{i}}$-type G-proteins. Other Drosophila receptors, tyramine/octopamine receptor (Arakawa et 

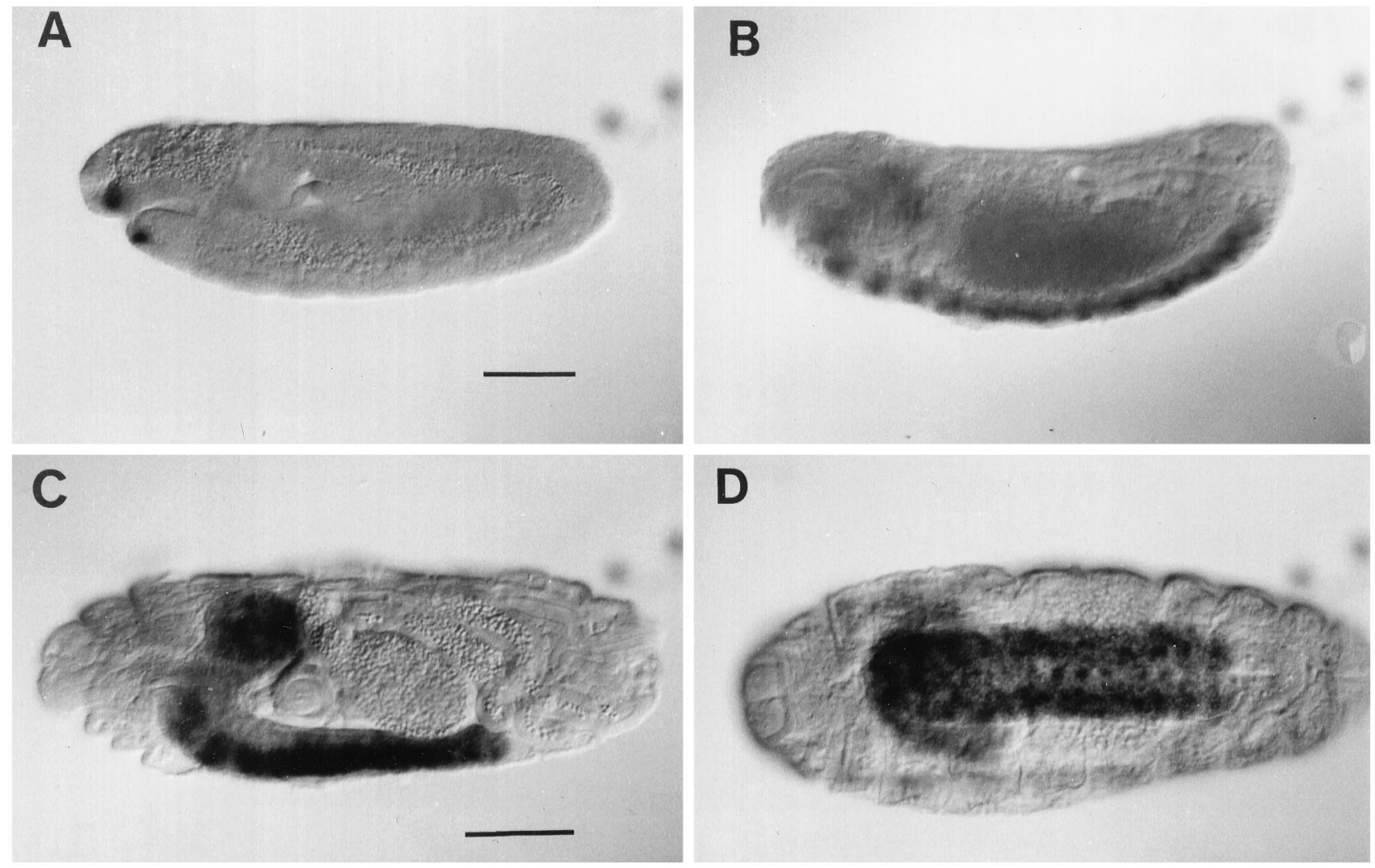

Figure 4. In situ hybridization on whole-mount embryos with a digoxigenin-labeled antisense DmGluRA probe. In $A-D$, anterior is on the left, and when the view is lateral, dorsal is on the top. $A$, Stage 10 embryo, lateral view. $B$, Stage 14 embryo, lateral view, same scale as $A$. $C$, stage 16 embryo, lateral view. $D$, Stage 16 embryo, ventral view, same scale as $C$. Scale bar, $100 \mu \mathrm{m}$.

al., 1990; Saudou et al., 1990) and $5 \mathrm{HT}_{1 \mathrm{ADro}}$ and $5 \mathrm{HT}_{1 \mathrm{BDro}}$ receptors (Saudou et al., 1992; Colas et al., 1995), also couple to mammalian $\mathrm{G}_{\mathrm{i}} / \mathrm{o}$ proteins.

DmGluRA coupling to G-proteins was examined further using $\mathrm{G}_{\alpha \mathrm{i} i} / \mathrm{o}$ chimeric G-proteins. Like other $\mathrm{G}_{\mathrm{i}} / \mathrm{o}_{\mathrm{o}}$-coupled GPCRs (Conklin et al., 1993), DmGluRA is able to activate these chimeric $G_{\alpha q} / o$ subunits but does not activate the wild-type $G_{\alpha q}$. Similar results were obtained with the rat mGluR2 and mGluR4 (Gomeza et al., 1996b). Therefore, the C-terminal region of the

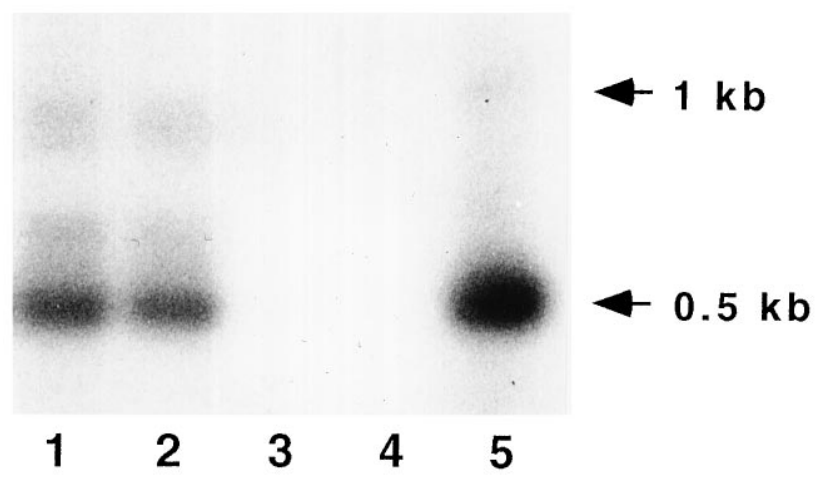

Figure 5. PCR analysis of the expression pattern of DmGluRA in the adult. PCR products of $485 \mathrm{bp}$ length, hybridizing with a radiolabeled DmGluRA probe, were obtained from heads (lane 1) and the remaining body fraction (lane 2) as well as from the positive control performed on the DmGluRA cDNA (lane 5). Lanes 3 and 4 are negative controls of RT (PCR reaction realized on the product of RT made without RNAs) and PCR (PCR reaction realized without any substrate), respectively. $\alpha$-subunit is also critical for the specific coupling of G-proteins to mGluRs. Moreover, these results suggest that DmGluRA can couple to Drosophila $\mathrm{G}_{\alpha \mathrm{i}}$ and $\mathrm{G}_{\alpha \mathrm{o}}$ proteins (Provost et al., 1988; Thambi et al., 1989). Interestingly, like DmGluRA, $G_{\alpha o}$ protein is expressed in the embryonic CNS. Therefore, in its native environment, DmGluRA may not only inhibit AC activity but may also regulate the activity of $\mathrm{K}^{+}$and $\mathrm{Ca}^{2+}$ channels (Harris-Warrick et al., 1988; Birnbaumer and Birnbaumer, 1995).

Taken together, these results indicate that DmGluRA shares a similar G-protein-coupling specificity with its mammalian homologs. We recently reported that i2 of mGluRs plays a critical role in defining the G-protein-coupling specificity of these receptors (Gomeza et al., 1996a). This is in contrast to most other GPCRs in which i3 plays such a role (Liu et al., 1995). In agreement with this proposal, the residues conserved in the second intracellular loop of $\mathrm{G}_{\mathrm{i}}$-coupled rat mGluRs, but not in PLC-coupled ones, are also conserved in DmGluRA (Fig. 1). Interestingly, a proline residue found in the C-terminal part of i2 in all mammalian mGluRs is not conserved in DmGluRA (Fig. 1, position 730 of DmGluRA). Although a proline residue is likely to be important for the secondary structure of this loop, our observation that DmGluRA has the same G-protein-coupling specificity as group II and III rat mGluRs suggests that this residue is not critical for a functional and specific coupling of these receptors to G-proteins.

The pharmacology of DmGluRA is similar to that of group II mammalian mGluRs (Tanabe et al., 1992, 1993; Pin and Duvoisin, 1995). This is remarkable because the amino acid identity of DmGluRA with mGluR2/3 in the supposed glutamate binding 
domain, i.e., the region homologous to bacterial periplasmic proteins, is only $45 \%$. This means that the critical amino acids that determine the pharmacophore of mGluR2/3 are conserved in DmGluRA. Such a pharmacological profile conservation for G-protein-coupled receptors is seldom observed through evolution. Drosophila peptide receptors (Li et al., 1991, 1992; Monnier et al., 1992), cloned Drosophila serotonin receptors 5-HT1ADro, 5-HT 1BDro, and 5-HT $_{7 \text { Dro }}$ (Witz et al., 1990; Saudou et al., 1992; Colas et al., 1995), the cloned Drosophila dopamine receptor (Gotzes et al., 1994), and the invertebrate octopamine and tyramine receptors (Arakawa et al., 1990; Saudou et al., 1990; Roeder, 1995), considered to be noradrenergic receptor homologs, display important pharmacological differences with their mammalian homologs; however, the recently cloned 5- $\mathrm{HT}_{2}$ Drosophila receptor is clearly pharmacologically related to the mammalian homolog 5-HT2B (Colas et al., 1995).

A first transient expression of DmGluRA revealed by in situ hybridization takes place at stage 10 . From the comparison with the fate map established at this stage (Jürgens et al., 1986), we suppose that the posterior labial labeling is situated within the hypopharyngeal presumptive territory, whereas the anterior labial labeling is situated within the clypeolabrum presumptive territory. More work is necessary, however, to determine which cell types express this mRNA and whether this is of any physiological relevance. A second period of expression of DmGluRA starts at stage 14 in the CNS and culminates at stage 17 when the larval CNS is formed. This expression is nearly synchronous with the expression of glutamate in motoneurones, which is first observed at 12.5-13.0 hr after egg laying (stage 15) (Broadie and Bate, 1993). Moreover, DmGluRA transcription appears at a period of neuronal differentiation and synaptogenesis. Indeed, the contact between motoneurones and their muscle target occurs at 12.513.0 $\mathrm{hr}$ AEL, and synaptic proteins begin to be expressed at stage 14 (DiAntonio et al., 1993). It is therefore likely that DmGluRA plays a role in embryonic glutamatergic synapses and is possibly involved in CNS development. Interestingly, mGluR5 and the mammalian DmGluRA homolog mGluR3 are expressed at a high level during the first postnatal weeks when synaptogenesis occurs (Catania et al., 1994; Romano et al., 1996). A role for these receptors in CNS development has therefore been proposed.

Taken together, these results indicate that in addition to ionotropic receptors, metabotropic glutamate receptors are also present in Drosophila, suggesting major roles for glutamate in the CNS of insects. The functions of these receptors, in either the development or physiology of the adult nervous system, will be approached further using genetic analysis.

\section{REFERENCES}

Aiba A, Kano M, Chen C, Stanton ME, Fox GD, Herrup K, Zwingman TA, Tonegawa S (1994) Deficient cerebellar long-term depression and impaired motor learning in mGluR1 mutant mice. Cell 79:377-388.

Arakawa S, Gocayne JD, McCombie WR, Urquhart DA, Hall LM, Fraser CM, Venter JC (1990) Cloning, localization and permanent expression of a Drosophila octopamine receptor. Neuron 2:343-354.

Bicker G, Schaefer S, Ottersen OP, Storm-Mathisen J (1988) Glutamatelike immunoreactivity in identified neuronal populations of insect nervous systems. J Neurosci 8:2108-2122.

Birnbaumer L, Birnbaumer M (1995) Signal transduction by G proteins: 1994 edition. J Recept Signal Transduct Res 15:213-252.

Bolshakov VY, Gapon SA, Magazanik LG (1991) Different types of glutamate receptors in isolated and identified neurones of the mollusc Planorbarius Corneus. J Physiol (Lond) 439:15-35.

Broadie KS, Bate M (1993) Development of the embryonic neuromuscular synapse of Drosophila melanogaster. J Neurosci 13:144-166.
Brown EM, Gamba G, Riccardi D, Lombardi M, Butters R, Kifor O, Sun A, Hediger MA, Lytton J, Hebert SC (1993) Cloning and characterization of an extracellular $\mathrm{Ca}_{2}^{+}$-sensing receptor from bovine parathyroid. Nature 366:575-580.

Cartmell J, Curtis AR, Kemp JA, Kendall DA, Alexander SPH (1993) Subtypes of metabotropic excitatory amino acid receptor distinguished by stereoisomers of the rigid glutamate analogue, 1-aminocyclopentane1,3-dicarboxylate. Neurosci Lett 153:107-110.

Catania MV, Landwehrmeyer GB, Testa CM, Standeart DG, Penney JB, Young AB (1994) Metabotropic glutamate receptors are differentially regulated during development. Neuroscience 61:481-495.

Cavener DR (1987) Comparison of the consensus sequences flanking translational start sites in Drosophila and vertebrates. Nucleic Acids Res 15:1353-1361.

Chomczynski P, Sacchi N (1987) Single-step method of RNA isolation by acid guanidium thiocyanate-phenol-chloroform extraction. Anal Biochem 162:156-159.

Colas JF, Launay JM, Kellermann O, Rosay P, Maroteaux L (1995) Drosophila 5-HT2 serotonin receptor: coexpression with fushi-tarazu during segmentation. Proc Natl Acad Sci USA 92:5441-5445.

Conklin BR, Bourne HR (1993) Structural elements of $\mathrm{G} \alpha$ subunits that interact with $G \beta \gamma$, receptors, and effectors. Cell 73:631-641.

Conklin BR, Farfel Z, Lustig KD, Julius D, Bourne HR (1993) Substitution of three amino acids switches receptor specificity of $\mathrm{Gq} \alpha$ to that of Gi $\alpha$. Nature 363:274-276.

Conquet F, Bashir ZI, Davies CH, Daniel H, Ferraguti F, Bordi F, Franz-Bacon K, Reggiani A, Matarese V, Condé F, Colingridge GL, Crépel F (1994) Motor deficit and impairment of synaptic plasticity in mice lacking mGluR1. Nature 372:237-243.

Cully DF, Vassilatis DK, Liu KK, Paress PS, Van der Ploeg LHT, Schaeffer JM, Arena JP (1994) Cloning of an avermectin-sensitive glutamategated chloride channel from Caenorhabditis elegans. Nature 371:707-711.

Delgado R, Barla R, Latorre R, Labarca P (1989) L-glutamate activates excitatory and inhibitory channels in Drosophila larval muscle. FEBS Lett 243:337-342.

DiAntonio A, Burgess RW, Chin AC, Deitcher DL, Scheller RH, Schwarz TL (1993) Identification and characterization of Drosophila genes for synaptic vesicle proteins. J Neurosci 13:4924-4935.

Dudek SM, Bear MF (1989) A biochemical correlate of the critical period for synaptic modification in the visual cortex. Science 246:673-675.

Gomeza J, Joly C, Kühn R, Knöpfel T, Bockaert J, Pin J-P (1996a) The second intracellular loop of mGluR1 cooperates with the other intracellular domains to control coupling to G-protein. J Biol Chem 271:2199-2205.

Gomeza J, Mary S, Brabet I, Parmentier M-L, Restituito S, Bockaert J, Pin J-P (1996b) Coupling of mGluR2 and mGluR4 to G $\alpha 15, \mathrm{G} \alpha 16$ and chimeric $\mathrm{G} \alpha \mathrm{q} / \mathrm{i}$ proteins: characterization of new antagonists. Mol Pharmacol, in press.

Gotzes F, Balfanz S, Baumann A (1994) Primary structure and functional characterization of a Drosophila dopamine receptor with high homology to human D1/5 receptors. Receptors Channels 2:131-141.

Harris-Warrick R, Hammond C, Paupardin-Tritsch D, Homburger V, Rouot B, Bockaert J, Gerschenfeld HM (1988) The $\alpha$ subunit of a GTP binding protein homologous to mammalian Go $\alpha$ mediates a dopamine-induced decrease of calcium current in snail neurons. Neuron $1: 27-32$.

Hart AC, Sims S, Kaplan JM (1995) Synaptic code for sensory modalities revealed by $C$. elegans GLR-1 glutamate receptor. Nature 378:82-85.

Hayashi Y, Tanabe Y, Aramori I, Masu M, Shimamoto K, Ohfune Y, Nakanishi S (1992) Agonist analysis of 2-(carboxycyclopropyl)glycine isomers for cloned metabotropic glutamate receptors subtypes expressed in Chinese hamster ovary cells. Br J Pharmacol 107:539-543.

Hayashi Y, Momiyama A, Takahashi T, Ohishi H, Ogawa-Meguro R, Shigemoto R, Mizuno N, Nakanishi S (1993) Role of a metabotropic receptor in synaptic modulation in the accessory olfactory bulb. Nature 366:687-690.

Hayashi Y, Sekiyama N, Nakanishi S, Jane DE, Sunter DC, Birse EF, Udvarhelyi PM, Watkins JC (1994) Analysis of agonist and antagonist activities of phenylglycine derivatives for different cloned metabotropic glutamate receptor subtypes. J Neurosci 14:3370-3377.

Hollmann M, Heinemann S (1994) Cloned glutamate receptors. Annu Rev Neurosci 17:31-108. 
Hutton ML, Harvey RJ, Barnard EA, Darlison MG (1991) Cloning of a cDNA that encodes an invertebrate glutamate receptor subunit. FEBS Lett 292:111-114.

Ito I, Kohda A, Tanabe S, Hirose E, Hayashi M, Mitsunaga S, Sugiyama H (1992) 3,5-dihydroxyphenyl-glycine: a potent agonist of metabotropic glutamate receptors. NeuroReport 3:1013-1016.

Jan LY, Jan YN (1976) L-glutamate as a neurotransmitter at the neuromuscular junction. J Physiol (Lond) 262:215-236.

Joly C, Gomeza J, Brabet I, Curry K, Bockaert J, Pin JP (1995) Molecular, functional, and pharmacological characterization of the metabotropic glutamate receptor type 5 splice variants: comparison with mGluR1. J Neurosci 15:3970-3981.

Jürgens G, Lehmann R, Schardin M, Nûsslein-Volhard C (1986) Segmental organization of the head in the embryo of Drosophila melanogaster. Roux's Arch Dev Biol 195:359-377.

Kaba H, Hayashi Y, Higuchi T, Nakanishi S (1994) Induction of an olfactory memory by the activation of a metabotropic glutamate receptor. Science 265:262-264.

Kehoe J (1994) Glutamate activates a $\mathrm{K}^{+}$conductance increase in Aplysia neurons that appears to be independent of $\mathrm{G}$ proteins. Neuron 13:691-702.

Law SF, Yasuda K, Bell GI, Reisine T (1993) $\mathrm{G}_{\mathrm{i} \alpha 3}$ and $\mathrm{G}_{\mathrm{o} \alpha}$ selectively associate with the cloned somatostatine receptor subtype SSTR2. J Biol Chem 268:10721-10727.

Lehmann R, Tautz D (1994) In situ hybridization to RNA. In: Drosophila melanogaster: practical uses in cell and molecular biology (Goldstein LSB, Fyrberg EA, eds), pp 576-598. San Diego: Academic.

Li XJ, Wolfgang W, Wu YN, North RA, Forte M (1991) Cloning, heterologous expression and developmental regulation of a Drosophila receptor for tachykinin-like peptides. EMBO J 10:3221-3229.

Li XJ, Wu YN, North RA, Forte M (1992) Cloning, functional expression and developmental regulation of a neuropeptide Y receptor from Drosophila melanogaster. J Biol Chem 267:9-12.

Liu J, Conklin BR, Blin N, Yun J, Wess J (1995) Identification of a receptor/G-protein contact site critical for signaling specificity and G-protein activation. Proc Natl Acad Sci USA 92:11642-11646.

Maricq AV, Peckol E, Driscoll M, Bargmann CI (1995) Mechanosensory signalling in $C$. elegans mediated by the GLR-1 glutamate receptor. Nature 378:78-81.

Masu M, Iwakabe H, Tagawa Y, Miyoshi T, Yamashita M, Fukuda Y, Sasaki H, Hiroi K, Nakamura Y, Shigemoto R, Takada M, Nakamura K, Nakao K, Katsuki M, Nakanishi S (1995) Specific deficit of the ON response in visual transmission by targeted disruption of the mGluR6 gene. Cell 80:757-765.

Monnier D, Colas JF, Rosay P, Hen R, Borelli E, Maroteaux L (1992) NKD, a developmentally regulated tachykinin receptor in Drosophila. J Biol Chem 267:1298-1302.

Nakanishi S (1994) Metabotropic glutamate receptors: synaptic transmission, modulation, and plasticity. Neuron 13:1031-1037.

O'Hara PJ, Sheppard PO, Thøgersen H, Venezia D, Haldeman BA, McGrane V, Houamed KM, Thomsen C, Gilbert TL, Mulvihill ER (1993) The ligand-binding domain in metabotropic glutamate receptors is related to bacterial periplasmic binding proteins. Neuron 11:41-52.

Pardue M-L (1994) Looking at polytene chromosomes. In: Drosophila melanogaster: practical uses in cell and molecular biology (Goldstein LSB, Fyrberg EA, eds), pp 334-370. San Diego: Academic.

Parker D (1994) Glutamatergic transmission between antagonistic motor neurones in the locust. J Comp Physiol [A] 175:737-748.

Pin J-P, Duvoisin R (1995) The metabotropic glutamate receptors: structure and functions. Neuropharmacology 34:1-26.
Pin J-P, Joly C, Heinemann SF, Bockaert J (1994) Domains involved in the specificity of $\mathrm{G}$ protein activation in phospholipase $\mathrm{C}$ coupled metabotropic glutamate receptor. EMBO J 13:342-348.

Provost NM, Somers DE, Hurley JB (1988) A Drosophila melanogaster G protein alpha subunit gene is expressed primarily in embryos and pupae. J Biol Chem 263:12070-12076.

Roberts PJ (1995) Pharmacological tools for the investigation of metabotropic glutamate receptors (mGluRs): phenylglycine derivatives and other selective antagonists-an update. Neuropharmacology 34:813-819.

Roeder T (1995) Pharmacology of the octopamine receptor from locust central nervous tissue (OAR 3). Br J Pharmacol 114:210-216.

Romano C, Van Den Pol AN, O'Malley KL (1996) Enhanced early developmental expression of the metabotropic glutamate receptor mGluR5 in rat brain: protein, mRNA splice variants, and regional distribution. J Comp Neurol 367:403-412.

Saudou F, Amlaiky N, Plassat JL, Borelli E, Hen R (1990) Cloning and characterization of a Drosophila tyramine receptor. EMBO J 9:3611-3617.

Saudou F, Boschert U, Amlaiky N, Plassat J-L, Hen R (1992) A family of Drosophila serotonin receptors with distinct intracellular signalling properties and expression pattern. EMBO J 11:7-17.

Schuster CM, Ultsch A, Schloss P, Cox JA, Schmitt B, Betz H (1991) Molecular cloning of an invertebrate glutamate receptor subunit expressed in Drosophila muscle. Science 254:112-114.

Stühmer T, Amar M, Harvey RJ, Bermudez I, Van Minnen J, Darlison MG (1996) Structure and pharmacological properties of a molluscan glutamate-gated cation channel and its likely role in feeding behavior. J Neurosci 16:2869-2880.

Tanabe Y, Masu M, Ishii T, Shigemoto R, Nakanishi S (1992) A family of metabotropic glutamate receptors. Neuron 8:169-179.

Tanabe Y, Nomura A, Masu M, Shigemoto R, Mizuno N, Nakanishi S (1993) Signal transduction, pharmacological properties, and expression patterns of two rat metabotropic glutamate receptors, mGluR3 and mGluR4. J Neurosci 13:1372-1378.

Thambi NC, Quan F, Wolfgang WJ, Spiegel A, Forte M (1989) Immunological and molecular characterization of Go $\alpha$-like proteins in the Drosophila central nervous system. J Biol Chem 264:18552-18560.

Ultsch A, Schuster CM, Laube B, Schloss P, Schmitt B, Betz H (1992) Glutamate receptors of Drosophila melanogaster: cloning of a kainateselective subunit expressed in the central nervous system. Proc Natl Acad Sci USA 89:10484-10488.

Ultsch A, Schuster CM, Laube B, Betz H, Schmitt B (1993) Glutamate receptors of Drosophila melanogaster: primary structure of a putative NMDA receptor protein expressed in the head of the adult fly. FEBS Lett 324:171-177.

Wilson R, Ainscough R, Anderson K, Baynes C, Berks M, Bonfield J, Burton J, Connell M, Copsey T, Cooper J, Coulson A, Craxton M, Dear S, Du Z, Durbin R, Favello A, Fraser A, Fulton L, Gardner A, Green P, Hawkins T, Hillier L, Jier M, Johnston L, Jones M, Kershaw J, Kirsten J, Laisster N, Latreille P, Lightning J, Lloyd C, Mortimore B, O'Callaghan M, Parsons J, Percy C, Rifken L, Roopra A, Saunders D, Shownkeen R, Sims M, Smaldon N, Smith A, Smith M, Sonnhammer E, Staden R, Sulston J, Thierry-Mieg J, Thomas K, Vaudin M, Vaughan K, Waterston R, Watson A, Weinstock L, Wilkinson-Sproat J, Wohldman $\mathrm{P}$ (1994) $2.2 \mathrm{Mb}$ of contiguous nucleotide sequence from chromosome III of C. elegans. Nature 368:32-38.

Witz P, Amlaiky N, Plassat J-L, Maroteaux L, Borelli E, Hen R (1990) Cloning and characterization of a Drosophila serotonin receptor that activates adenylate cyclase. Proc Natl Acad Sci USA 87:8940-8944. 